\title{
First signs of late blight resistance in traditional native potatoes of Pasco-Peru, a preliminary assay
}

\author{
Edith Zevallos ${ }^{1}$, Josue Inga ${ }^{1}$, Fernando Alvarez ${ }^{1}$, Karina Marmolejo ${ }^{1}$, Rocio Paitan ${ }^{1}$, Ines Viza ${ }^{1}$, Dante Becerra ${ }^{1}$, \\ Gina Rixi ${ }^{1}$ and Cecilia Silva-Diaz ${ }^{2 *}$ (])
}

\begin{abstract}
Background: The native Andean potatoes, despite their low yield, have a large diversity that is conserved by subsistence farmers in Peru, due to their culinary characteristics and other qualities. However, this diversity is threatened by the impacts of climate change, which would directly affect the food security of these people, and eventually ours. Among its qualities of resistance to pests and diseases, there could be a genetic source of resistance to late blight, one of the most damaging diseases of the potato crop in the world. In this assay, 103 native landraces collected from local farmers in the Pasco region of Peru were subjected to natural infection conditions with Phytophthora infestans to identify potential resistant landraces within them.
\end{abstract}

Results: The 103 landraces assessed showed a broad variety of responses and were classified as "resistant" (22\%), "moderately resistant" (57\%), and "susceptible landraces" (21\%). A relative effect of the disease in the yield is also shown, which is already low for commercial intentions.

Conclusion: Within this representative sample of the native potato diversity of the Pasco region, at least 23 local varieties grown by subsistence farmers have resistance qualities against eventual late blight disease.

Keywords: Potato landraces, Andean highlands, Subsistence farmers, Climate change, Food security

\section{Introduction}

Andean native potato landraces own a high diversity that contributes as an important source of resistance against pests and diseases, and possess valuable qualities such as chipping quality, high solids content, resistance to frost, and medicinal uses [1]. Despite having a very low average yield (7 t/ha) [2], farmers keep them for cultural heritage and food safety, because of their good taste and softness after cooking [3]. Notwithstanding, the difficult and time-consuming labor, the cultivation of native potatoes

\footnotetext{
*Correspondence: silvadiaz.cc@gmail.com

2 Universidad Nacional Agraria La Molina (UNALM), Av. La Molina s/n Lima, Peru
}

Full list of author information is available at the end of the article is a source of pride for older community members in particular [4].

Over the past few decades, this diversity is decreasing due to lack of access to water for irrigation, lack of recognition of indigenous people to own their land, changes in agricultural practices, migrations of inhabitants to urban areas, the impossibility of obtaining clean potato seeds of their local landraces, and the restricted access to markets $[1,3]$. In addition, forecasted scenarios state that climate change will increase temperatures in cold highlands that could promote the proliferation of pests and diseases in these areas [5].

One of the most detrimental diseases of the potato crop in the world is late blight (LB), and so is in Peru [2]. The LB disease is caused by the pathogen Phytophthora infestans (Mont.) de Bary, and is sensitive to weather original author(s) and the source, provide a link to the Creative Commons licence, and indicate if changes were made. The images or other third party material in this article are included in the article's Creative Commons licence, unless indicated otherwise in a credit line to the material. If material is not included in the article's Creative Commons licence and your intended use is not permitted by statutory regulation or exceeds the permitted use, you will need to obtain permission directly from the copyright holder. To view a copy of this licence, visit http://creativecommons.org/licenses/by/4.0/. The Creative Commons Public Domain Dedication waiver (http://creativeco mmons.org/publicdomain/zero/1.0/) applies to the data made available in this article, unless otherwise stated in a credit line to the data. 
conditions, thus a warmer and more humid environment-due to climate change-will be a great challenge for farmers [6]. Studies have found that a $20 \%$ increase in LB severity could cause a $1 \mathrm{t} /$ ha reduction in yield [7].

In the Peruvian Andes, subsistence agriculture is rainfed, which forces farmers to plant potatoes during rainy season-the season for major P. infestans attack-[7]. There is the case of the peasant community Challabamba located at 4100 m.a.s.l. (meters above the sea level) in Cusco-Peru, where climate change has caused the loss of $90 \%$ of its native potato diversity due to LB [2]. The disease affects farmers in other aspects as well: when the fungicides damage the leaves, the photosynthetic capacity is reduced and consequently, crop yield; it is also risky for their health, and represents an income lost [8]. Traditionally, farmers have used highlands as late blight-free areas, planting more susceptible potato varieties because of low temperatures inhibiting the disease [5]. However, climate change effects could force them to go into more fragile ecosystems, such as Paramo and Puna lands in the Andes, with direct impact on soil organic carbon reservoirs [9].

Over the years, there have been many studies and attempts to combat the disease without complete success. Among the reasons for this, could be the ability of the pathogen to evolve over time, as well as the variable level of resistance of a genotype that depends on the place where it lives, which together would cause the resistance genotype less effective [8]. In fact, $P$. infestans is known to be a highly variable pathogen which easily adapts to factors restricting its development, such as systemic fungicides [10]. Furthermore, considering the strong influence of climate, the actual resistance of varieties may not be known in all locations [8].

In the Pasco region, farmers produce potato landraces under an indigenous farming system called "Chaqru" in the Quechua language, and like in the Huancavelica region-center of high intraspecific diversity-they plant a mixture of native bitter and floury cultivars that correspond to various species with different ploidy levels [11]. The most common Solanum species found in the Central Andes are S. stenotomum $(2 \times)$, S. goniocalyx $(2 \times), S$. chaucha $(3 \times)$ and $S$. tuberosum subsp. andigenum $(4 \times)$ that contains the majority of landraces in a mixed potato field [12]. Referring to the farmers culinary preferences, they have three primary "use-categories" in which the mentioned species are located: "boiling potato" (S. stenotomum, S. goniocalyx, $S . \times$ chaucha and S. tuberosum subsp. andigena), "soup potato" (S. tuberosum subsp. tuberosum), and "freeze-drying potato" (S. curtilobum and $S . \times$ juzepczukii) [13]. Yet, little is known about the incidence and severity of pests and diseases on traditional landraces of the region [14].
To support farmers adapt to climate change impacts is necessary to contribute to a better description and understanding of those impacts on potato crop in its center of origin [5]. According to Byarugaba et al. [15] and Gabriel et al. [16], the most economical and environmentally feasible solution to control LB is to sow a host resistance, which is why many research programs are still looking for genetic resistance in native or wild species for contributing to extreme climatic conditions adaptation [17]. This study was carried out to identify native potato landraces traditionally cultivated in the Pasco region with potential field resistance to Phytophthora infestans.

\section{Materials and methods Location}

An on-farm field trial was carried out at the Yanay peasant community, in Paucartambo, Pasco region, Peru $\left(10^{\circ}\right.$ $45^{\prime} 56.3^{\prime \prime} \mathrm{S} 75^{\circ} 46^{\prime} 22.7^{\prime \prime}$ W, 2745 m.a.s.l.) from December 4th, 2020 to February 23rd, 2021 during the rainy season. The site's weather is characterized by an annual rainfall of $1010.1 \mathrm{~mm}$, and average relative humidity of $60.7 \pm 1.4 \%$, in addition to average values of maximum, medium and minimum temperature of $19.0 \pm 0.2,11.8 \pm 0.2$ and $7.0 \pm 2.1{ }^{\circ} \mathrm{C}$, respectively [18]. The place is known for having LB presence on crops (E. Zevallos, personal comment). During the evaluation period (59 days), the accumulated rainfall and average values of relative humidity, maximum and minimum temperature were $228.6 \mathrm{~mm}$, $83.4 \pm 0.6 \%, 16.3 \pm 0.2{ }^{\circ} \mathrm{C}$, and $8.7 \pm 0.1{ }^{\circ} \mathrm{C}$, respectively (Fig. 1). Due to technical issues, these data were obtained as reference from NASA POWER access data [19].

\section{Plant material and management}

The genotypes assessed in this trial are part of a collection of 358 traditional potato landraces from subsistence farmer's fields in the Pasco region, made by the UNDAC Native Potatoes Project. The collection is maintained at natural highlands conditions $\left(10^{\circ} 45^{\prime} 06.8^{\prime \prime} \mathrm{S} 75^{\circ} 47^{\prime} 53.4^{\prime \prime}\right.$ W, 3555 m.a.s.l.), where native varieties are normally cultivated by locals, and the same genotypes were grown in a greenhouse ( $10^{\circ} 46^{\prime} 14.1^{\prime \prime} \mathrm{S} 75^{\circ} 48^{\prime} 53.4^{\prime \prime} \mathrm{W}, 2949$ m.a.s.l.), since August 20th, 2020. At the greenhouse (12 h photoperiod; $15-20{ }^{\circ} \mathrm{C}$ ) each individual came from a tuber sprout planted in a pot filled with $6 \mathrm{~kg}$ mixture of sphagnum moss, perlite, vermiculite, and arable land that was irrigated at field capacity $(750 \mathrm{ml})$. On December 4th, 2020 (106 days after planting-DAP), a selection of those with better market qualities and available replications was taken to the field at a height where improved varieties are cultivated, for assessing LB resistance under natural infection conditions in the open field, and irrigated by rainfall. This type of study is used to select large populations of potato genotypes [20]. The next day, Greenzit 


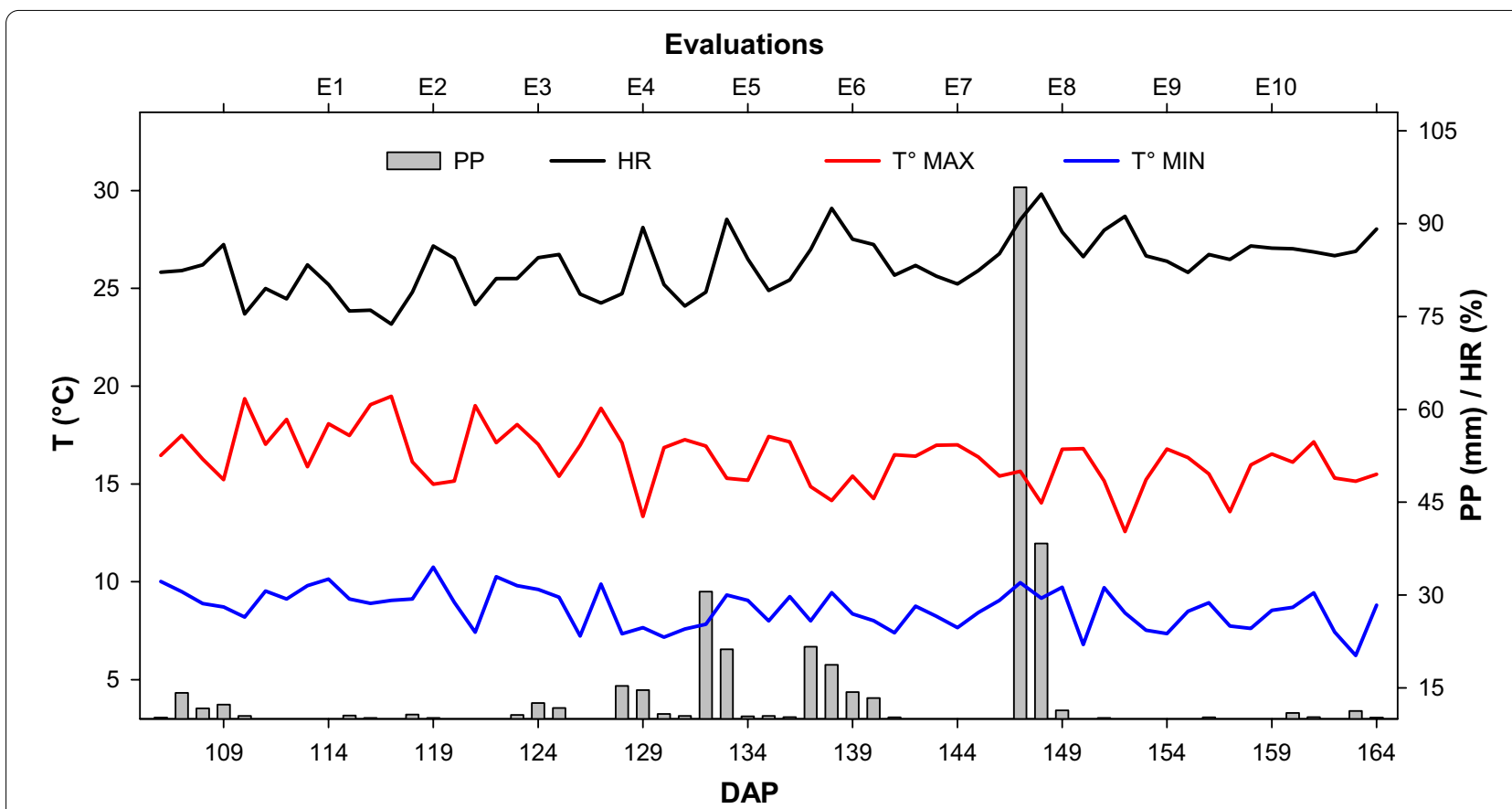

Fig. 1 Relative humidity (RH), maximum and minimum temperature (TP MAX and MIN), and precipitation (PP) during the evaluation period (106-164 days after planting-DAP)

pH (Neoagrum, Peru), Cyperklin 25 (TQC, Peru), and Antracol (Bayer, Germany) were applied to protect plants until evaluations. The harvest was made on February 23rd, 2021 (187 DAP); where a preliminary fresh tuber yield (FTY) was calculated from the fresh weight of the total number of tubers collected per plant.

\section{Experimental design}

In the field, the pots (experimental unit) were distributed in a randomized block design, with three replications (composed by a single pot) per landrace. Based on local knowledge, the accession UNDAC_153 representative of the landrace "Cajacino" was considered as a susceptible control. In addition, four known susceptible varieties were included within each block as dispersal genotypes ("Yungay", "Canchán", "Negra andina", and "Huayro"). The separation between pots was $0.35 \mathrm{~m}$ long and $0.9 \mathrm{~m}$ wide, simulating plant density used by local farmers. The total area occupied by the experimental units was $102 \mathrm{~m}^{2}$.

\section{Evaluation of late blight resistance}

A visual inspection was carried out to estimate the percentage of leaf area affected by $P$. infestans every 5 days, starting at 114 DAP. These data were used to calculate the area under the disease progress curve (AUDPC), a single measure that quantifies the amount of disease in an epidemic, widely used in the literature. However, it is only applicable within a single experiment, for which the relative AUDPC (rAUDPC) has been proposed as a standardized and more stable measure, but still with limited use to quantify susceptibility [21]. The scale of susceptibility (SS) applied in this study is an adaptation to the conditions of the tropical highlands agroecosystems made by Yuen and Forbes [21], because the common references come from European cultivars that are not well suited to these conditions.

For the inspection, three composite leaves were selected at each experimental unit (one from the lower, middle and upper third), and a standardized scale was used to determine the percentage of leaves affected by LB, following [22]. The calculus of AUDPC responds to Eq. 1, where " $t$ " is the time of every measurement in DAP, " $y$ " the percentage of foliage affected in each inspection and " $n$ ", the number of inspections [20]:

$$
\operatorname{AUDPC}=\sum_{i=1}^{n-1}\left(\frac{y_{i}+y_{i+1}}{2}\right)\left(t_{i+1}-t_{i}\right)
$$

The rAUDPC is calculated by dividing the AUDPC by the "maximum potential AUDPC", the value that a genotype would have with $100 \%$ of infection at every measurement, and is obtained from multiplying the total number of days between the first $\left(I_{\mathrm{f}}\right)$ and last $\left(I_{\mathrm{l}}\right)$ inspection by 100 [20]: 


$$
\mathrm{rAUDPC}=\frac{\text { AUDPC }}{\left(\mathrm{I}_{\mathrm{l}}-\mathrm{I}_{\mathrm{f}}\right) \times 100}
$$

The SS is the value of the standard genotype coefficient (the most susceptible can receive a measure of $\approx$ 9) multiplied by the observed rAUDPC of the candidate genotype $\left(\mathrm{rAUDPC}_{\mathrm{o}}\right)$ and divided by the rAUDPC of the standard genotype $\left(\mathrm{rAUDPC}_{\mathrm{s}}\right)$, which is chosen carefully [21]:

$$
\mathrm{SS}=9 \times \frac{\text { rAUDPC }_{\mathrm{O}}}{\mathrm{rAUDPCs}}
$$

\section{Statistical analysis}

For determining significant differences between the accessions, it was applied an analysis of variance (ANOVA) and a Tukey test from the "Agricolae" package [23]. In addition, a correlation between the AUDPC values and tuber yield was made for assessing the effects of LB on potato yield. All the analyses were run using $\mathrm{R}$ Studio software [24].

\section{Results}

The first evidence of LB affectation on the assessed accessions of Pasco region's traditional potato landraces was registered in the second evaluation (December 17th, 2020). From this date, the disease incidence spread quickly until the sixth evaluation (January 6th, 2021), where the complete 103 accessions (Table 1) showed disease symptoms in at least one of their replications (Fig. 2).

The ANOVA reported statistical differences between accessions and also between blocks (Table 2). From the assay, it was obtained that the $21 \%$ of the assessed landraces presented AUDPC values between 1239 and 1827, with a high susceptibility scale ranging between 6 and 9 (Fig. 3A). The second group corresponded to the $57 \%$ of the total landraces, with an AUDPC range of [829-1230] and a SS between 4 and 5 (Fig. 3B). The last 23 landraces with the lowest AUDPC values [392-799] represented the $22 \%$ of the whole plant material, with SS values between 2 and 3 (Fig. 3C). The complete dataset used for the results is available on Additional file 1.

Within the accessions assessed, UNDAC_153 had a rAUDPC $=0.45$ in one of its repetitions and received a $\mathrm{SS}=9$ for working as reference [20]. "Cajacino" was part of the top five AUDPC values (Fig. 4A). The first signs of infection on some of UNDAC_153 replications were recorded in the fourth evaluation (December 27th, 2021). All the individuals had more than $90 \%$ of infection in the tenth evaluation (January 21st, 2021), with a standard error of $14 \%$ between replications. The other landraces with similar responses were "Manzana I", "Tumbay I",
"Queqorani I", and "Común ojo negro" (Fig. 4A). On the opposite side, the five landraces with lowest AUDPC values ("Ichis puro", "Pampiña", "Puca rosa", "Negro callash", and "Mosqueña") had a very similar behavior against $P$. infestans (Fig. 4B). The first signs of infection appeared on the seventh evaluation (January 11th, 2021), and until the last one (January 26th, 2021) their highest values remained below $60 \%$ of infection.

The preliminary fresh tuber yield varied widely from accessions with fresh weight under $100 \mathrm{~g} /$ plant in 34 of the total landraces assessed, to those within the range of $100-200 \mathrm{~g} /$ plant (61 accessions). The highest values were between 200 and $336 \mathrm{~g} /$ plant, and corresponded to only eight landraces ("Garhua suytu", "Shashai warmi I", "Puca clavelina", "Juyu huayro", "Chiaquil rosado", "Mosqueña”, "Morales rojo", and "Negro callash"). The correlation between AUDPC and FTY was $r=-0.40$.

\section{Discussions}

The rapid onset and spreading of LB along the 103 native potatoes assessed at 2745 m.a.s.l. on the central highlands of Peru demonstrated the presence of the pathogen $P$. infestans and the proper environmental conditions for the development of the disease in the place. Two decades ago, the International Potato Center considered the presence of the disease in other areas from the Pasco region [20] that set a precedent for the study objectives: assessing LB resistance under natural infection conditions. Typically, these landraces are grown at higher elevations in the Andean highlands, where $P$. infestans may not be present yet due to low temperatures. For the purpose of the study, the accessions were cultivated at a medium altitude where improved cultivars are sown but also have latent presence of the pathogen, mainly between 2800 and 3500 m.a.s.l. [16].

The sharp increase of disease incidence from third (5\% of all accessions) to fourth evaluation (50\% of all accessions) within 5 days could be promoted by the cumulative precipitation since 1st day open field $(23.15 \mathrm{~mm})$ and elevated relative humidity (about $80 \%$ ) during those days (Fig. 1), considering that the pathogen can complete the cycle from infection to sporulation in 4 days [25]. Nevertheless, the assay showed a broad variability of responses to the disease, which were grouped according to susceptibility scale (SS) ranges and those from Fig. 3A (SS $=6-9)$ could be considered as "susceptible landraces", Fig. 3B (SS $=4-5)$ as "moderately resistant", and Fig. 3C $(\mathrm{SS}=2-3)$ as "resistant" [20]. The lowest AUDPC values-part of Fig. 3C-were due to a late onset and a slow development of the infection, which is how a resistant cultivar responds [16].

Within the complete list of landraces, there were some accessions with the same folk name. According to 
Table 1 Accessions of landraces from the Pasco region, subjected to natural epidemic conditions of Phytophthora infestans from December 2020 to February 2021

\begin{tabular}{|c|c|c|c|c|c|c|c|}
\hline Code & Folk name & rAUDPC & ss & Code & Folk name & rAUDPC & SS \\
\hline UNDAC_4 & Coleto & $0.29 \pm 0.07$ & 5.7 & UNDAC_133 & Milagro & $0.26 \pm 0.04$ & 5.1 \\
\hline UNDAC_8 & Amarilla legítima & $0.24 \pm 0.04$ & 4.7 & UNDAC_134 & Pillush & $0.28 \pm 0.04$ & 5.6 \\
\hline UNDAC_14 & Azul siqui & $0.29 \pm 0.05$ & 5.9 & UNDAC_139 & Yurac maco & $0.28 \pm 0.07$ & 5.6 \\
\hline UNDAC_18 & Queqorani I & $0.35 \pm 0.01$ & 7 & UNDAC_141 & Leona & $0.23 \pm 0.03$ & 4.7 \\
\hline UNDAC_23 & Muru huayro & $0.25 \pm 0.04$ & 5 & UNDAC_142 & Queqorani II & $0.19 \pm 0.04$ & 3.8 \\
\hline UNDAC_24 & Barcaza & $0.28 \pm 0.03$ & 5.6 & UNDAC_146 & Sunccu suwacc & $0.14 \pm 0.01$ & 2.7 \\
\hline UNDAC_26 & Huayro moro & $0.27 \pm 0.05$ & 5.5 & UNDAC_147 & Negra pestaña blanca & $0.22 \pm 0.04$ & 4.3 \\
\hline UNDAC_29 & Chaulina & $0.17 \pm 0.02$ & 3.4 & UNDAC_151 & Vitelote & $0.25 \pm 0.03$ & 5 \\
\hline UNDAC_32 & Pico de oro & $0.28 \pm 0.06$ & 5.6 & UNDAC_153 & Cajacino & $0.36 \pm 0.05$ & 7.3 \\
\hline UNDAC_33 & Muru alljupu nuy & $0.21 \pm 0.05$ & 4.2 & UNDAC_157 & Chaucha cunvians & $0.23 \pm 0.03$ & 4.7 \\
\hline UNDAC_42 & Ishco puro amarillo & $0.15 \pm 0.04$ & 3 & UNDAC_160 & Huanuqueñito & $0.28 \pm 0.04$ & 5.7 \\
\hline UNDAC_43 & Ichis puro & $0.11 \pm 0.02$ & 2.3 & UNDAC_163 & Jara callu & $0.31 \pm 0.02$ & 6.1 \\
\hline UNDAC_48 & Yurac mata & $0.16 \pm 0.01$ & 3.3 & UNDAC_164 & Huanuco suytu & $0.27 \pm 0.08$ & 5.3 \\
\hline UNDAC_49 & Comun ojo negro & $0.33 \pm 0.04$ & 6.6 & UNDAC_168 & Higo suytu & $0.2 \pm 0.03$ & 4 \\
\hline UNDAC_51 & Escuela nueva & $0.13 \pm 0.03$ & 2.6 & UNDAC_169 & Callhuan & $0.29 \pm 0.01$ & 5.7 \\
\hline UNDAC_52 & Queso suytu & $0.11 \pm 0.01$ & 2.3 & UNDAC_170 & Pikura & $0.27 \pm 0.03$ & 5.4 \\
\hline UNDAC_53 & Coleto suytu & $0.23 \pm 0.03$ & 4.6 & UNDAC_171 & Negro callash & $0.09 \pm 0.01$ & 1.8 \\
\hline UNDAC_55 & Amachi & $0.22 \pm 0.01$ & 4.4 & UNDAC_172 & Cocho negro & $0.25 \pm 0.05$ & 5 \\
\hline UNDAC_57 & Sonia canteña & $0.21 \pm 0.03$ & 4.2 & UNDAC_178 & Valicha & $0.16 \pm 0.03$ & 3.3 \\
\hline UNDAC_58 & Seda galleta & $0.2 \pm 0.03$ & 3.9 & UNDAC_182 & Yurac allua & $0.17 \pm 0.01$ & 3.3 \\
\hline UNDAC_59 & Tumbay I & $0.39 \pm 0.04$ & 7.8 & UNDAC_184 & Camotillo & $0.23 \pm 0.06$ & 4.6 \\
\hline UNDAC_60 & Pampiña & $0.11 \pm 0.02$ & 2.2 & UNDAC_188 & Garhua suytu & $0.24 \pm 0.05$ & 4.8 \\
\hline UNDAC_61 & Shiruco & $0.12 \pm 0.04$ & 2.4 & UNDAC_190 & Puca clavelina & $0.14 \pm 0.02$ & 2.9 \\
\hline UNDAC_65 & Capiag blanco & $0.22 \pm 0.05$ & 4.5 & UNDAC_191 & Huacapa gallum & $0.24 \pm 0.01$ & 4.7 \\
\hline UNDAC_72 & Tatash & $0.17 \pm 0.01$ & 3.4 & UNDAC_193 & Yuquis suytu & $0.14 \pm 0.01$ & 2.8 \\
\hline UNDAC_74 & Galleta roja & $0.13 \pm 0.01$ & 2.5 & UNDAC_195 & Chiaquil rosado & $0.23 \pm 0.04$ & 4.5 \\
\hline UNDAC_76 & Puca rosa & $0.1 \pm 0.01$ & 2.1 & UNDAC_196 & Yurac piña & $0.26 \pm 0.05$ & 5.1 \\
\hline UNDAC_77 & Huayro moro rojo & $0.16 \pm 0.01$ & 3.1 & UNDAC_198 & Manzana II & $0.41 \pm 0.01$ & 8.1 \\
\hline UNDAC_79 & Rosada & $0.3 \pm 0.09$ & 6 & UNDAC_200 & Shashai warmi I & $0.28 \pm 0.02$ & 5.5 \\
\hline UNDAC_84 & Wichi wichi & $0.17 \pm 0.04$ & 3.4 & UNDAC_201 & Negra milagro & $0.28 \pm 0.04$ & 5.6 \\
\hline UNDAC_85 & Tarmeña & $0.25 \pm 0.03$ & 5 & UNDAC_202 & Rojiza acaclui pecho & $0.25 \pm 0.02$ & 5 \\
\hline UNDAC_92 & Huamali & $0.21 \pm 0.02$ & 4.2 & UNDAC_203 & Yana cauriña & $0.26 \pm 0.07$ & 5.1 \\
\hline UNDAC_95 & Conchucano & $0.31 \pm 0.02$ & 6.2 & UNDAC_206 & Santo domingo & $0.23 \pm 0.06$ & 4.7 \\
\hline UNDAC_97 & Clavel suytu & $0.22 \pm 0.02$ & 4.4 & UNDAC_208 & Morales rojo & $0.19 \pm 0.05$ & 3.8 \\
\hline UNDAC_100 & Yawar suytu & $0.22 \pm 0.07$ & 4.3 & UNDAC_212 & Muru cauriña & $0.2 \pm 0.05$ & 4 \\
\hline UNDAC_101 & Suytu rojo & $0.27 \pm 0.02$ & 5.4 & UNDAC_214 & Huayro moro liso & $0.26 \pm 0.05$ & 5.2 \\
\hline UNDAC_105 & Tumbay ॥ & $0.22 \pm 0.03$ & 4.3 & UNDAC_215 & Shashai warmi II & $0.19 \pm 0.02$ & 3.8 \\
\hline UNDAC_106 & Chiaquil & $0.18 \pm 0.02$ & 3.5 & UNDAC_218 & Gaiwa suytu & $0.18 \pm 0.02$ & 3.7 \\
\hline UNDAC_113 & Orgo runtush & $0.29 \pm 0.02$ & 5.8 & UNDAC_222 & Ganto suytu & $0.24 \pm 0.04$ & 4.8 \\
\hline UNDAC_114 & Huayta chuco & $0.31 \pm 0.03$ & 6.2 & UNDAC_224 & Mosqueña & $0.09 \pm 0.02$ & 1.7 \\
\hline UNDAC_117 & Mama lucha & $0.27 \pm 0.05$ & 5.4 & UNDAC_226 & Yurac negro & $0.2 \pm 0.04$ & 4 \\
\hline UNDAC_118 & Juyu huayro & $0.2 \pm 0.02$ & 4.1 & UNDAC_230 & Paña tahuina & $0.26 \pm 0.07$ & 5.2 \\
\hline UNDAC_120 & Corta & $0.23 \pm 0.01$ & 4.7 & UNDAC_232 & Yana tulo & $0.19 \pm 0.03$ & 3.9 \\
\hline UNDAC_121 & Jilguero & $0.21 \pm 0.03$ & 4.3 & UNDAC_239 & Pampa machay & $0.19 \pm 0.02$ & 3.8 \\
\hline UNDAC_122 & Huamantanga & $0.19 \pm 0.02$ & 3.7 & UNDAC_249 & Jerga suytu & $0.21 \pm 0.06$ & 4.2 \\
\hline UNDAC_123 & Pallanchacrina & $0.21 \pm 0.03$ & 4.1 & UNDAC_250 & Conchuna & $0.19 \pm 0.01$ & 3.9 \\
\hline UNDAC_125 & Manzana I & $0.19 \pm 0.02$ & 3.8 & UNDAC_251 & Niña papa & $0.2 \pm 0.03$ & 4 \\
\hline
\end{tabular}


Table 1 (continued)

\begin{tabular}{|c|c|c|c|c|c|c|c|}
\hline Code & Folk name & rAUDPC & SS & Code & Folk name & rAUDPC & SS \\
\hline UNDAC_126 & Colorada & $0.21 \pm 0.02$ & 4.3 & UNDAC_252 & Higos & $0.26 \pm 0.04$ & 5.1 \\
\hline UNDAC_127 & Huayllino rojo & $0.26 \pm 0.03$ & 5.3 & UNDAC_255 & Yana juyto & $0.28 \pm 0.08$ & 5.7 \\
\hline UNDAC_129 & Rojo ayacuchana & $0.25 \pm 0.01$ & 5 & UNDAC_256 & Chucas & $0.15 \pm 0.01$ & 3.1 \\
\hline UNDAC_130 & Alga huayro & $0.21 \pm 0.04$ & 4.3 & UNDAC_259 & Muru chingus & $0.19 \pm 0.03$ & 3.9 \\
\hline UNDAC_131 & Huancaína & $0.16 \pm 0.05$ & 3.3 & & & & \\
\hline
\end{tabular}

rAUDPC Relative area under the disease progress curve, SS susceptibility scale based on Forbes et al. [20]

${ }^{\text {a }}$ Most of folk names are in Quechua language

Clausen et al. [1], this could be due to coming from a different locality or farmer and sharing morphological similarities, or the result of the exchange of varieties between farmers. In fact, time ago Zimmerer [12] stated that the spatial coalescence of endemic distributions conforms most closely to agricultural areas articulated through networks of seed exchange, so-called cultivar regions. Whereby, two accessions with the same folk name, e.g., "Corta", "Huamali", "Leona" and "Pampa machay" that came from different farmers or localities, and had similar AUDPC curve behavior with $\mathrm{SS}=5$, were assumed to be the same landrace and just one of them was conserved for the analysis. Only those with different AUDPC
Table 2 Analysis of variance between the assessed accessions

\begin{tabular}{llrrrr}
\hline & $\begin{array}{l}\text { Degree } \\
\text { of } \\
\text { freedom }\end{array}$ & $\begin{array}{l}\text { Sum } \\
\text { square }\end{array}$ & \multicolumn{1}{l}{$\begin{array}{l}\text { Mean } \\
\text { square }\end{array}$} & $\boldsymbol{F}$ value & $\operatorname{Pr}(>\boldsymbol{F})$ \\
\hline Accessions & 102 & $24,001,557$ & 235,309 & 3.526 & $9.49 \mathrm{e}^{-15 * * *}$ \\
Blocks & 1 & $4,439,849$ & $4,439,849$ & 66.532 & $3.41 \mathrm{e}^{-14 * * *}$ \\
Residuals & 205 & $13,680,147$ & 66,732 & & \\
\hline
\end{tabular}

Significance codes: 0 i***t

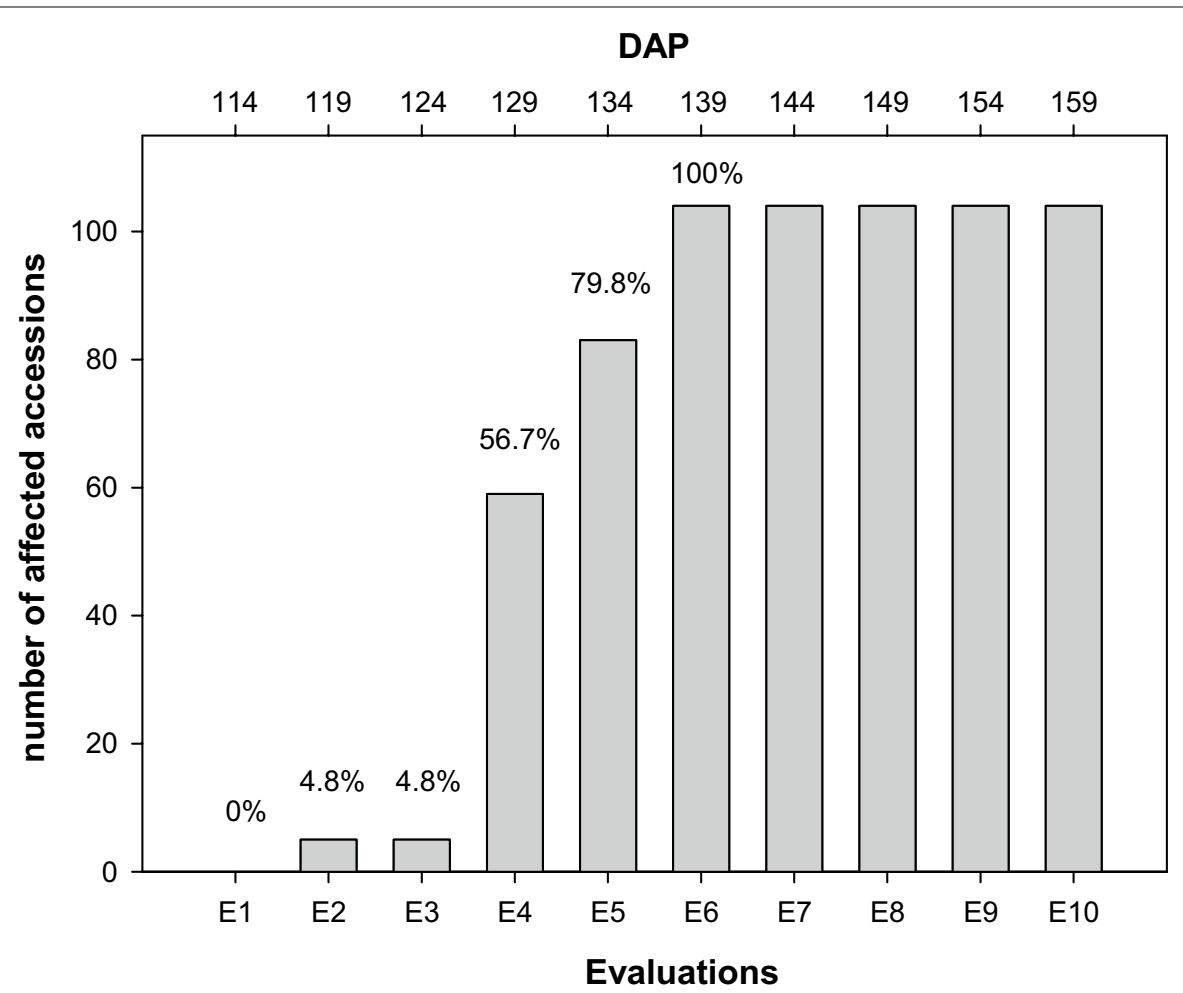

Fig. 2 Disease incidence across the 103 accessions assessed in the evaluation period (106-164 days after planting —DAP) 









curve behavior were considered different and kept with a Roman numeral added to the name. It is not possible to assume that those with different behaviors were genetically different without molecular analysis. If many accessions were representatives of the same genotype with different behavior against $P$. infestans, it could be an expression of wide resistance related to horizontal resistance [10].

Regarding the crop yield, the influence of LB could not be assured because of the low correlation $(r=-0.4)$ between them, but when considering only "resistant landraces" the negative correlation slightly increases $(r=-0.6)$. Almost $70 \%$ of the landraces had a FTY greater than $110 \mathrm{~g} / \mathrm{plant}$, with the maximum values over $300 \mathrm{~g} /$ plant. Although it does not exist statistics on the annual production of native potatoes in Peru [26], a recent study with native potatoes from Peru showed FTY values (considering 20\% dry matter) between 500 and $3000 \mathrm{~g} /$ plant under optimal conditions [27]. Another publication, a catalog of native potato varieties from Apurimac-an agrobiodiverse region of Peru-presented FTY of 500-1450 g/plant [28]. When comparing to these, it is evident that the LB disease affected yield. It is not feasible to establish the proportion of the impact due to preliminary yield data. These landraces are typically harvested after 8 months of cultivation, but this study was carried out at 6 months. Still, preliminary yield allows predictions of its final values, which strongly influence the selection, e.g., for breeding programs [29]. Given that a resistant genotype maintains an acceptable production during the rainy season [30], it is proposed that those within the group (Fig. 3C) and with a yield greater than 200 g/plant, such as "Puca clavelina", "Negro callash" and "Mosqueña" could withstand a high pressure of the disease, or in times of low pressure, they would respond better than the rest.

The reasons for maintaining these types of landraces despite their low yield rely in farmer's culinary preferences, based in cultivar mixtures for home consumption, the co-existence with other crops, and the fact that the marketable varieties subsidize the maintenance of noncommercial potato landraces [31]. Therefore, they maintain an ecologically dynamic agro-ecosystem [1].

Finally, the statistical difference between blocks according to ANOVA may have been biased by the small sample size, since it was only one plant representing an accession at each block. Given the large number of landraces evaluated, it was difficult to assess more repetitions for each one. However, it should also be considered that the AUDPC trait is sensitive to a lack of homogeneity of the disease in open field conditions [20]. The rAUDPC could be useful to compare with future trials within the UNDAC Native Potatoes Project and other studies.

\section{Conclusion}

This preliminary assay suggests that at least 23 native potatoes landraces cultivated by subsistence farmers from the Pasco region present a potential resistance to late blight that could contribute as genetic resources for food security. It is necessary to continue with this type of study in other areas and seasons to be aware of what is happening with native landraces in the Andean 
highlands, which is the ideal scenario to evaluate the impacts of climate change.

\author{
Abbreviations \\ UNDAC: National University Daniel Alcides Carrion; LB: Late blight; m.a.s.l.: \\ Meters above sea level; DAP: Days after planting; FTY: Fresh tuber yield; \\ AUDPC: Area under the disease progress curve; rAUDPC: Relative AUDPC; SS: \\ Susceptibility scale; ANOVA: Analysis of variance.
}

\section{Supplementary Information}

The online version contains supplementary material available at https://doi. org/10.1186/s40066-021-00330-9.

Additional file 1. Tabular data in XLS format. "Dataset of the assay". The file contains the data of all the variables assessed for each individual, and the environmental data recorded during the experiment.

\section{Acknowledgements}

The authors thank the Central Research Institute (ICI) from Pasco's National University Daniel Alcides Carrion (UNDAC) for funding the project "Identification of genes resistant to biotic and abiotic stressors, and physiology of native potato landraces from the Pasco region". We also thank to Eudys Gavilán and Holbein Poma for their technical support in the field, and Rachel Elfant for the English writing review.

\section{Authors' contributions}

$E Z$, Jl, FA and KM participated in the conception and design of the study; GR and IV in the project administration; $E Z, G R$ and RP in the data collection; EZ, JI, FA, KM, RP. IV, DB, GR and CSD in the data analysis; CSD in the manuscript writing; and all the authors made a final critical revision. All authors read and approved the final manuscript.

\section{Funding}

The study was funded by the Central Research Institute from Pasco's National University Daniel Alcides Carrion (28103.65 US\$) through the project "Identification of genes resistant to biotic and abiotic stressors, and physiology of native potato landraces from the Pasco region".

\section{Availability of data and materials}

All data generated or analyzed during this study are included in this published article [and its additional information files].

\section{Declarations}

Ethics approval and consent to participate

Not applicable.

\section{Consent for publication}

Not applicable.

\section{Competing interests}

The authors declare that they have no competing interests.

\section{Author details}

${ }^{1}$ Universidad Nacional Daniel A. Carrión (UNDAC), San Juan Pampa, P.O. 12000, Cerro de Pasco, Pasco, Peru. ${ }^{2}$ Universidad Nacional Agraria La Molina (UNALM), Av. La Molina s/n, Lima, Peru.

Received: 1 April 2021 Accepted: 25 July 2021

Published online: 04 September 2021

\section{References}

1. Clausen AM, Ispizúa VN, Digilio A. Native Andean potato varieties in Argentina: conservation and evaluation of an endangered genetic resource. Am J Plant Sci Biotechnol. 2010;12:72-89.

2. Pacheco MA, Gastelo M, Landeo J, Puente de la Vega E, de Haan S. Dos nuevas variedades de papa (Solanum tuberosum spp andigena) con resistencia horizontal al tizón tardío, seleccionadas por las comunidades altoandinas del Cusco, Perú a través de la selección varietal participativa. Cusco, Perú; 2010.

3. Monteros AÁ. On-farm conservation of potato landraces in Ecuador. Agron Colomb. 2018;36:189-200.

4. Tobin D, Bates R, Brennan M, Gill T. Peru potato potential: Biodiversity conservation and value chain development. Renew Agric Food Syst. 2016;33:19-32.

5. Quiroz R, Ramírez DA, Kroschel J, Andrade-Piedra J, Barreda C, Condori B, et al. Impact of climate change on the potato crop and biodiversity in its center of origin. Open Agric. 2018;3:273-83.

6. Giraldo D, Juarez H, Pérez W, Trebejo I, Yzarra W, Forbes G. Severidad del tizón tardío de la papa (Phytophthora infestans) en zonas agrícolas del Perú asociado con el cambio climático. Rev Peruana Geo-Atmosférica. 2010;12.

7. Ortiz O, Winters P, Fano H. La Percepción de los agricultores sobre el problema del tizón tardío o rancha (Phytophthora infestans) su manejo: estudio de casos en Cajamarca, Perú. RALAP. 1999;11:97-120.

8. Salazar L, Winters P, Maldonado L, Hareau G, Thiele G. Assessing the impact of late blight, vol. 40. Lima: CIP; 2009.

9. Segnini A, Posadas A, Quiroz R, Milori DMBP, Vaz CMP, Martin-Neto L. Soil carbon stocks and stability across an altitudinal gradient in southern Peru. J Soil Water Conserv. 2011;66:213-20.

10. Colon L. Resistance to Phytophthora infestans in Solanum tuberosum and wild Solanum species. Wageningen University and Research: Wageningen; 1994.

11. de Haan S, Almekinders C, Thiele G, Ccanto R, Scurrah M. Seed procurement of native potatoes in the central Andes of Peru: the role of farmer-to-farmer exchange, markets and seed fairs. 2009;13.

12. Zimmerer KS. The regional biogeography of native potato cultivars in highland Peru. J Biogeogr. 1991;18:165.

13. Brush S, Kesseli R, Ortega R, Cisneros P, Zimmerer KS, Quiros C. Potato diversity in the Andean center of crop domestication. Conserv Biol. 1995;9:1189-98.

14. Pérez Barrera W, Valverde Miraval M, Barreto Bravo M, Andrade-Piedra J, Forbes GA. Pests and diseases affecting potato landraces and bred varieties grown in Peru under indigenous farming system. RALAP. 2015;19:29-41.

15. Byarugaba AA, Prossy N, Kashaija IN. Identification of potato clones of population B3C2 with durable field resistance to late blight (Phytophthora infestans) and high yields in Uganda. Afr J Agric Res. 2013;8:3055-3059.

16. Gabriel J, Condori B, Gandarillas A, Plata G. Qué está pasando con el clima y el tizón de la papa [Phytophthora infestans (Mont.) De Bary] en Bolivia. Rev Latinoamericana de la Papa. 2019;23:63-75.

17. Thomas G, Sansonetti G, Food and Agriculture Organization of the United Nations. New light on a hidden treasure: International Year of the Potato 2008 , an end-of-year review. Rome: Food and Agriculture Organization of the United Nations; 2009.

18. Santos Malpartida PA. Diseño y ejecución de la línea principal y laterales para riego a presión en el anexo de Aco del distrito de Paucartambo-Pasco. Lima: Universidad Nacional Agraria La Molina; 2017.

19. NASA POWER: Prediction of Worldwide Energy Resources database. https:// power.larc.nasa.gov/data-access-viewer/. Accessed 27 Feb 2021.

20. Forbes GA, PerezW, Andrade-Piedra J. Metodologías de evaluación estándar y manejo de datos de clones avanzados de papa. Módulo 2: Evaluación del rendimiento de tubérculos sanos de clones avanzados de papa, guía para colaboradores internacionales. International Potato Center; 2014.

21. Yuen JE, Forbes GA. Estimating the level of susceptibility to Phytophthora infestans in potato genotypes. Phytopathology ${ }^{\circledR}$. 2009;99:782-6.

22. Barquero M, Gómez L, Brenes A. Resistencia al tizón tardío (Phytophthora infestans) en clones. Agron Costarricense. 2005;16

23. de Mendiburu F.Tutorial de Agricolae (Versión 1.2-8). 2017.

24. R Core Team. A language and environment for statistical computing. Vienna: $\mathrm{R}$ Foundation for Statistical Computing. https://www.R-project.org/.

25. Kamoun S, Furzer O, Jones JDG, Judelson HS, Ali GS, Dalio RJD, et al. The top 10 oomycete pathogens in molecular plant pathology: top 10 oomycete plant pathogens. Mol Plant Pathol. 2015;16:413-34. 
26. Scott GJ. Plants, people, and the conservation of biodiversity of potatoes in Peru. NatCon. 2011;9:21-38.

27. Silva-Díaz C, Ramírez DA, Rinza J, Ninanya J, Loayza H, Gómez R, et al. Radiation interception, conversion and partitioning efficiency in potato landraces: how far are we from the optimum? Plants. 2020;9:787.

28. PRODERN. La papa nativa en Apurímac. Identificación participativa de variedades en los distritos de Huayna y Pomacocha. Lima, Peru; 2018. p. 170.

29. Michel S, Ametz C, Gungor H, Akgol B, Epure D, Grausgruber H, et al. Genomic assisted selection for enhancing line breeding: merging genomic and phenotypic selection in winter wheat breeding programs with preliminary yield trials. Theor Appl Genet. 2017:130:363-376.

30. Cáceres PA, Pumisacho M, Forbes GA, Andrade-Piedra JL. Guía para facilitar el aprendizaje sobre control de tizón tardío de la papa. Lima: Centro
Internacional de la Papa, Instituto Nacional Autónomo de Investigaciones Agropecuarias del Ecuador, Secretaría Nacional de Ciencia y Tecnología del Ecuador; 2007

31. de Haan S, Núñez J, Bonierbale M, Ghislain M. Multilevel agrobiodiversity and conservation of Andean potatoes in Central Peru: species, morphological, genetic, and spatial diversity. Mt Res Dev. 2010;30:222-31.

\section{Publisher's Note}

Springer Nature remains neutral with regard to jurisdictional claims in published maps and institutional affiliations. 